\title{
Abundance of Epiphytic Dinoflagellates from Coastal Waters off Jeju Island, Korea During Autumn 2009
}

\author{
Hyung Seop Kim ${ }^{1}$, Wonho Yih ${ }^{2 *}$, Jong Hyeok Kim ${ }^{2}$, Geumog Myung ${ }^{3}$, and Hae Jin Jeong ${ }^{4}$ \\ ${ }^{1}$ Research Institute of Fisheries Technology, Kunsan 573-882, Korea \\ ${ }^{2}$ Department of Oceanography, Kunsan National University, Kunsan 573-701, Korea \\ ${ }^{3}$ Western Branch, Korea Fisheries Resources Agency, Kunsan 573-030, Korea \\ ${ }^{4}$ School of Earth and Environmental Sciences, College of Natural Sciences, Seoul National University, Seoul 151-747, Korea
}

Received 23 June 2011; Revised 24 August 2011; Accepted 10 September 2011

(c) KSO, KORDI and Springer 2011

\begin{abstract}
The occurrence of harmful epiphytic dinoflagellates is of concern to scientists, the aquaculture industry, and government due to their toxicity not only to marine organisms but also to humans. There have been no studies on the abundance of the epiphytic dinoflagellates in Korean waters. We explored the presence of epiphytic dinoflagellates in the coastal waters off Jeju Island, southwestern Korea. Furthermore, we measured the abundance of epiphytic dinoflagellates on the thalli of 24 different macroalgae, collected from five different locations in October 2009. Five epiphytic dinoflagellate genera Amphidinium, Coolia, Gambierdiscus, Ostreopsis, and Prorocentrum were found. These five genera were observed on the thalli of the macroalgae Chordaria flagelliformis, Martensia sp., Padina arborescens, and Sargassum sp., while none were observed exceptionally on Codium fragile. The abundance of Ostreopsis spp. was highest on Derbesia sp. (8,660 cells/g wet weight), while that of Gambierdiscus spp. was highest on Martensia sp. (4,870 cells/g-ww). The maximum abundances of Amphidinium spp., Coolia spp., and Prorocentrum spp. were 410, 710, and 300 cells/g-ww, respectively. The maximum abundance of Coolia spp., Gambierdiscus spp., and Ostreopsis spp. obtained in the present study was lower than for other locations reported in literature. The results of the present study suggest that the presence and abundance of epiphytic dinoflagellates may be related to the macroalgal species of the coastal waters of Jeju Island.
\end{abstract}

Key words-Amphidinium, Gambierdiscus, HAB, Ostreopsis, Prorocentrum, red tide

\footnotetext{
*Corresponding author. E-mail: ywonho@kunsan.ac.kr
}

\section{Introduction}

Species in the genera Gambierdiscus, Ostreopsis, Coolia, Prorocentrum, and Amphidinium are known to be epiphytic and/or benthic dinoflagellates (Taylor 1979, 1995, Hurbungs et al. 2001). Most of the epiphytic dinoflagellates is harmful to humans as well as to marine organisms, to which scientists, the aquaculture industry, and government are keenly attentive (Bagnis et al. 1980; Alcala et al. 1988; Mangialajo et al. 2008). The majority of these dinoflagellates are known to be present in tropical or subtropical regions (Steidinger and Tangen 1997), but some species also live in the warm waters of temperate regions (Hurbungs et al. 2001; Pistocchi et al. 2011). The occurrence of epiphytic and benthic dinoflagellates in temperate waters has been reported as evidence of increasing water temperature (Graneli et al. 2011; Rhodes 2011).

Recently, Jeong et al. (submitted) reported the presence of Coolia spp. in the coastal waters of Jeju Island, southwestern Korea. However, this paper did not report the presence of the other epiphytic dinoflagellates at Jeju Island. We provide the first account of the occurrence of Gambierdiscus, Ostreopsis and epiphytic Prorocentrum and Amphidinium spp. from the coastal waters of Jeju Island. Additionally, we report the abundance of these epiphytic dinoflagellates, and the diverse macroalgal species on which they were found. The results of the present study should provide a basis for better understanding the ecology of epiphytic dinoflagellates in Korean waters. 


\section{Materials and Methods}

To measure the abundance of epiphytic dinoflagellates, macroalgal samples (24 different algal species) were collected by divers at 1-3 m depth off Hahnlim, Kosahn, Sahgye, Namwon, and Seongsan, Jeju Island, Korea (Fig. 1), on October 30 and November 1st, 2009. The water temperature and salinity were $21.0-23.6{ }^{\circ} \mathrm{C}$ and $29.2-31.6$, respectively (Table 1). The samples were placed in plastic bags and then fixed with buffered 3\% formaldehyde. Additional samples were placed in plastic bags, and then stored in ice-boxes, and then transported to the laboratory. The fixed macroalgal samples were vigorously shaken to detach dinoflagellates from the thalli of the algae and then screened through a $500 \mu \mathrm{m}$ Nitex mesh. Filtrates were concentrated to $1 / 5-1 / 10$ after settling down the cells for $48 \mathrm{~h}$. After being well mixed, all or $>300$ cells in one $1-\mathrm{ml}$ Sedgwick-Rafter counting chamber were counted under a light microscope. The wet weight of each macroalgal sample was measured using a balance (Model CUW620H, CAS, Korea). Cells (not preserved) were collected from the macroalgal samples and photographed using a digital camera (Zeiss AxioCam HRc5, Carl Zeiss Ltd. Göttingen, Germany).

\section{Results and Discussion}

Five epiphytic dinoflagellate genera Amphidinium, Coolia, Gambierdiscus, Ostreopsis, and Prorocentrum were found in the coastal waters of Jeju island, Korea on October 31

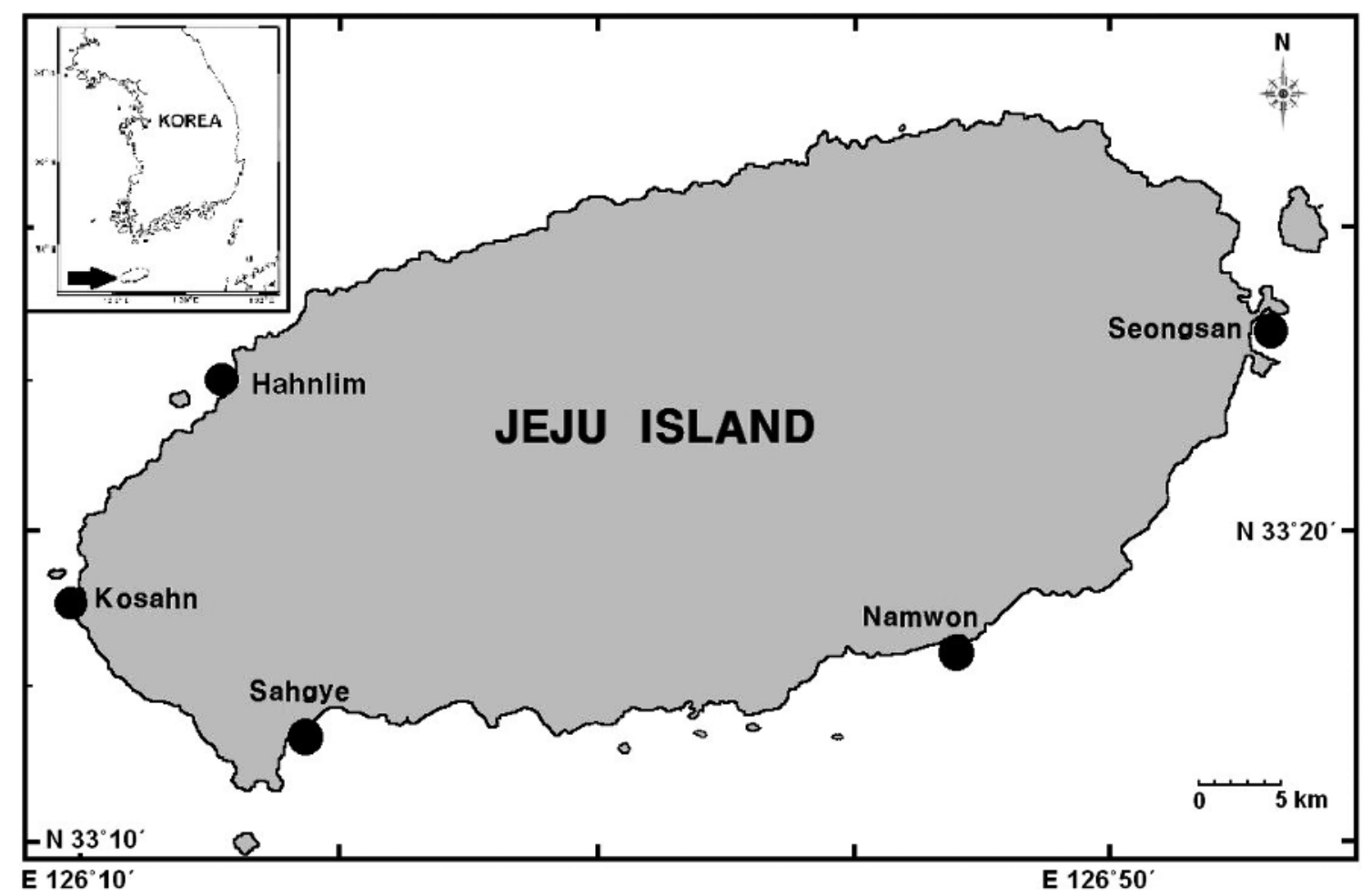

Fig. 1. The five sampling sites at Jeju Island, southwestern Korea

Table 1. Water temperature $\left(\mathrm{T},{ }^{\circ} \mathrm{C}\right)$ and salinity $(\mathrm{S})$ in the locations where macroalgae were collected on October 31 and November 1 , 2009

\begin{tabular}{|c|c|c|c|c|}
\hline Location & Latitude & Longitude & Temperature & Salinity \\
\hline Hahnlim & $\mathrm{N} 33^{\circ} 24^{\prime} 25.46^{\prime \prime}$ & E $126^{\circ} 14^{\prime} 30.02^{\prime \prime}$ & 21.1 & 28.9 \\
\hline Kosahn & N $33^{\circ} 17^{\prime} 52.30^{\prime \prime}$ & E $126^{\circ} 09^{\prime} 42.22^{\prime \prime}$ & 21.8 & 31.1 \\
\hline Sahgye & N 331'ㄱ․ & E $126^{\circ} 18^{\prime} 25.63^{\prime \prime}$ & 23.6 & 31.6 \\
\hline Namwon & N $33^{\circ} 16^{\prime} 28.99^{\prime \prime}$ & E $126^{\circ} 42^{\prime} 56.96^{\prime \prime}$ & 22.1 & 29.2 \\
\hline Seongsan & N $33^{\circ} 27^{\prime} 23.65^{\prime \prime}$ & E $126^{\circ} 55^{\prime} 45.37^{\prime \prime}$ & 21.0 & 32.5 \\
\hline
\end{tabular}



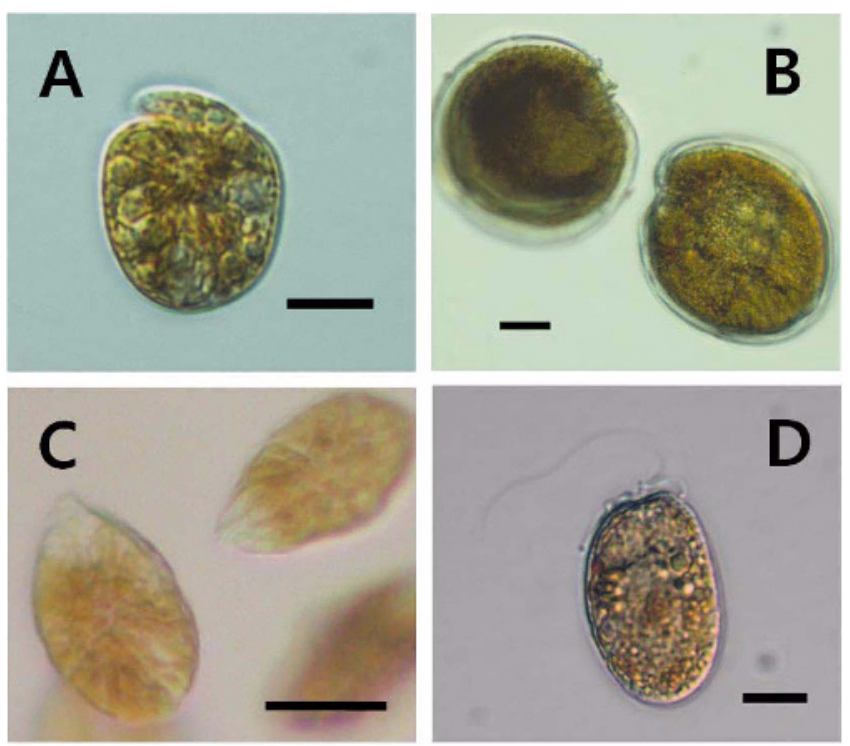

Fig. 2. Epiphytic dinoflagellates observed in this study. (A) Amphidinium sp. bar $=10$ um. (B) Gambierdiscus sp. bar $=20 \mu \mathrm{m}$. (C) Ostreopsis sp. bar $=20 \mu \mathrm{m}$. (D) Prorocentrum sp. bar $=10 \mu \mathrm{m}$ and November 1, 2009 (Fig. 2). All were observed on the thalli of the macroalgae Chordaria flagelliformis, Martensia sp., Padina arborescens, and Sargassum sp.. Furthermore, Coolia, Gambierdiscus, Ostreopsis, and Prorocentrum were observed on the thalli of the macroalgae Ulva pertusa, Ecklonia caba, and Chondrus ocellatus. However, none of these genera were observed with Codium fragile (Table 2). Amphidinium spp. were observed with seven macroalgal species (Cladophora wrightiana, Sargassum sp., Dictyopteris divaricata, C. flagelliformis, P. arborescens, and Martensia sp.), Coolia with seven macroalgal species (U. pertusa, E. caba, Sargassum sp., C. flagelliformis, P. arborescens, Martensia sp., and C. ocellatus), while Prorocentrum spp. with eight macroalgal species (U. pertusa, E. caba, Sargassum sp., D. divaricata, C. flagelliformis, P. arborescens, Martensia sp., Gelidium amansii, Corallina sp.). Gambierdiscus spp., were observed with all macroalgal species except $C$. fragile and Sargassum siliquastrum, while Ostreopsis spp. were observed with all macroalgal species except C. fragile,

Table 2. The abundance (cells/g wet weight) of the epiphytic dinoflagellates Amphidinium spp., Coolia spp., Gambierdiscus spp., Ostreopsis spp., Prorocentrum spp. on diverse macroalgae collected from 5 stations along the coasts of Jeju Island, Korea on October 31-November 1, 2009

\begin{tabular}{|c|c|c|c|c|c|c|}
\hline & Macroalgae\Epiphytes & Amphidinium & Coolia & Gambierdiscus & Ostreopsis & Prorocentrum \\
\hline \multirow[t]{5}{*}{ Chlorophyta } & Cladophora wrightiana & $0-15$ & 0 & 39 & 758 & 0 \\
\hline & Ulva pertusa & 0 & $0-237$ & 500 & 342 & $29-53$ \\
\hline & Cladophoropsis herpestica & 0 & 0 & 173 & 231 & 0 \\
\hline & Derbesia sp. & 0 & 0 & 1,595 & 8,660 & 0 \\
\hline & Codium fragile & 0 & 0 & 0 & 0 & 0 \\
\hline \multirow[t]{11}{*}{ Phaeophyta } & Dictyopteris prolifera & 0 & 0 & 60 & 164 & 0 \\
\hline & Ecklonia caba & 0 & $0-33$ & $17-53$ & $5-69$ & 8 \\
\hline & Dictyota okamurae & 0 & 0 & 1,000 & 185 & 0 \\
\hline & Sargassum siliquastrum & 0 & 0 & - & 121 & 0 \\
\hline & Sargassum sp. & $0-10$ & $0-121$ & 343 & 434 & 30 \\
\hline & Dictyopteris divaricata & $0-37$ & 0 & $13-200$ & $87-216$ & 12 \\
\hline & Chordaria flagelliformis & $0-121$ & $0-339$ & 1,770 & 364 & 97 \\
\hline & Zonaria diesingiana & 0 & 0 & 111 & $44-94$ & 0 \\
\hline & Padina arborescens & $0-137$ & $0-652$ & 789 & 583 & 171 \\
\hline & Colpomenia sinuosa & $0-68$ & 0 & 136 & 545 & 0 \\
\hline & Dictyopteris undulata & 0 & 0 & 62 & - & 0 \\
\hline \multirow[t]{8}{*}{ Rhodophyta } & Plocamium cartilagineum & 0 & 0 & 255 & 255 & 0 \\
\hline & Pterocladiella capillacea & 0 & 0 & 1,599 & 837 & 0 \\
\hline & Lithothamnion sp. & 0 & 0 & 25 & - & 0 \\
\hline & Martensia sp. & $0-406$ & $0-710$ & 4,871 & 3,349 & 304 \\
\hline & Gelidium amansii & 0 & 0 & $229-426$ & $78-688$ & 233 \\
\hline & Corallina sp. & 0 & 0 & $33-993$ & $28-307$ & 33 \\
\hline & Chondrus ocellatus & 0 & $0-47$ & 63 & 267 & 0 \\
\hline & Plocamium telfairiae & 0 & 0 & $406-1477$ & $50-966$ & 0 \\
\hline
\end{tabular}




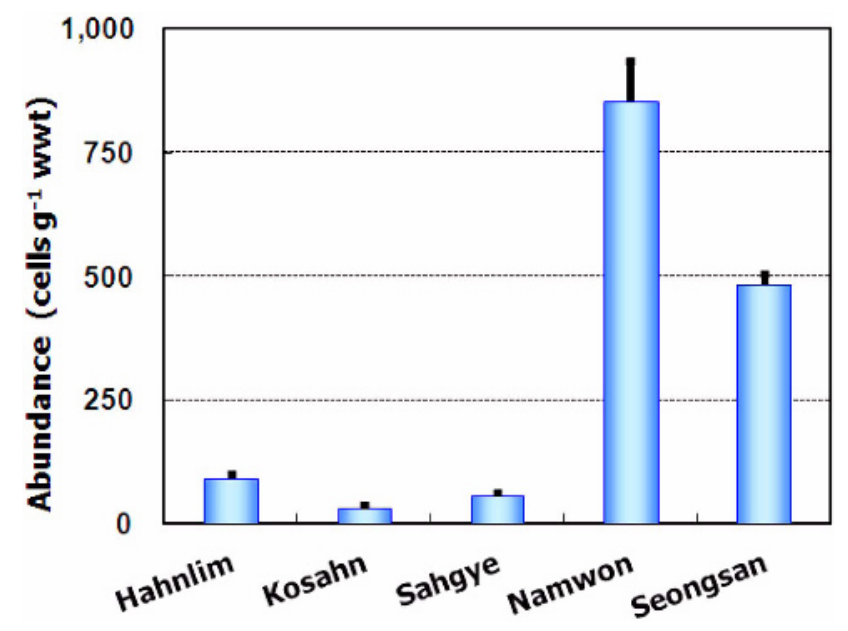

Fig. 3. Mean abundance of epiphytic dinoflagellates in each of the five stations. Error bar represents standard error of mean

Dictyopteris undulata, and Lithothamnion sp. (Table 2). The data suggest that the presence of these five epiphytic dinoflagellate genera is affected by the macroagal species in the study area.

The presence of the five epiphytic genera on the four macroalagal species, i.e. C. flagelliformis, Martensia sp., $P$. arborescens, and Sargassum sp., contrasts with their absence from a green alga, C. fragile. Codium fragile, however, was observed only at St. Kosahn where the coastline is more exposed than St. Namwon or Seongsan. Samples from St. Kosahn and Sahgye gave far lower abundance of epiphytic dinoflagellates than the other two embayment stations (Fig. 3). The unexpected absence of epiphytic dinoflagellates from Codium fragile and the far lower abundance on macroalgae from more exposed sites may be related with species interactions of the epiphytes with physical and biological environment. Shaking effect due to turbulent water at the open coast (physical-biological interaction) and/or diverse bi-species interaction among different macroalga-epiphyte combinations may limit or support their success (Bomber et al. 1989).

The evidence suggests that Derbesia sp. is the optimal macroalgae for Ostreopsis spp., while Martensia sp. may be the optimal macroalgae for the other dinoflagellate genera studied herein (Table 2). However, abundance of epiphytic dinoflagellate estimated by cells per unit weight of substrate macroalgal blade tends to become higher on such macroalgal species with higher surface to volume ratio as Derbesia sp. and Martensia sp..

The maximum abundance of Gambierdiscus spp. ( $\sim 5 \times$ $10^{3}$ cells/g ww) obtained in the present study is lower than that of G. toxicus from the Gambier Islands, Pacific Ocean $\left(500 \times 10^{3}\right.$ cells/g ww; Yasumoto et al. (1980). The maximum abundance of Ostreopsis spp. $\left(\sim 9 \times 10^{3}\right.$ cells/g ww) obtained in the present study is also quite lower than elsewhere $\left(400-2,500 \times 10^{3}\right.$ cells/g ww; Table 3$)$. This might imply that the environmental conditions in the study area is at sub-optimal level to the five epiphytic dinoflagellate genera, which are presumably "settling down and adapting themselves" to the increasing water temperature of Jeju coastal waters.

Table 3. Comparison of the maximum abundances (MA, $\times 10^{3}$ cells $/ g$ wet weight) of the epiphytic dinoflagellates Amphidinium spp., Coolia spp., Gambierdiscus spp., Ostreopsis spp., Prorocentrum spp. obtained in the present study and those reported in literature

\begin{tabular}{llll}
\hline \hline Genus & location & MA & Reference \\
\hline Amphidinium spp. & Jeju Island, Korea & 0.41 & This study \\
Coolia spp. & Jeju Island, Korea & 0.71 & This study \\
C. monotis & Virgin Islands, Caribbean Sea & 1,200 & Calson \& Tindall (1985) \\
Gambierdiscus spp. & Jeju Island, Korea & 4.87 & This study \\
G. toxicus & Gambier Islands, Pacific Ocean & 500 & Yasumoto et al.(1980) \\
Ostreopsis spp. & Jeju Island, Korea & 8.66 & This study \\
O. ovata & Genoa, Italy & 2,541 & Mangialajo et al. (2008) \\
O. siamensis & Auckland, New Zealand & 1,406 & Shears \& Ross (2009) \\
Ostreopsis sp. & NW Mediterranean Sea & 590 & Vila et al. (2001) \\
Ostreopsis spp. & North Aegean Sea, Greece & 405 & Aligizaki \& Nikolaidis (2006) \\
Prorocentrum spp. & Jeju Island, Korea & 0.30 & This study \\
P. mexicanum & Virgin Islands, Caribbean Sea & 1,500 & Calson \& Tindall (1985) \\
\hline
\end{tabular}




\section{Acknowledgements}

We thank Mr. Yong-Deok Ko for technical supports in collecting samples from subsurface waters. This paper was supported by the Infrastructuring Grant for Marine Biotechnology Program funded by Korea Institute of Marine Science \& Technology Promotion (KIMST)/Ministry of Land, Transportation and Marine Affairs (KMLTM) award to WH Yih, the National Research Foundation of Korea Grant funded by the Korea Government/MEST (NRF-C1ABA001-2010-0020700), and the Ecological Disturbance Research Program funded by KIMST/ KMLTM award to HJ Jeong.

\section{References}

Alcala AC, Alcala LC, Garth JS, Yasumura D, Yasumoto T (1988) Human fatality due to ingestion of the crab Demanda reynaudii that contained a palytoxin-like toxin. Toxicon 26:105-107

Aligizaki K, Nikolaidis G (2006) The presence of the potentially toxic genera Ostreopsis and Coolia (Dinophyceae) in the North Aegean Sea, Greece. Harmful Algae 5:717-730

Bagnis R, Chanteau S, Chungue E, Hurtel JM, Yasumoto T, Inoue A (1980) Origins of ciguatera fish poisoning : A new dinoflagellate, Gambierdiscus toxicus Adachi and Fukuyo, definitively involved as a causal agent. Toxicon 18:199-208

Bomber JW, Rubio MG, Norris DR (1989) Epiphytism of dinoflagellates associated with the disease ciguatera:substrate specificity and nutrition. Phycologia 28:360-368

Carlson RD, Tindall DR (1985) Distribution and periodicity of toxic dinoflagellates in the Virgin Islands. In: Anderson DM, White AW, Baden DG (eds) Toxic dinoflagellates. Elsevier, New York, pp 171-176

Granéli E, Vidyarathna NK, Funari E, Cumaranatunga P, Scenati R (2011) Can increases in temperature stimulate blooms of the toxic benthic dinoflagellate Ostreopsis ovata? Harmful Algae 10:165-172
Hurbungs MD, Jayabalan N, Chineah V (2001) Seasonal distribution of potentially toxic benthic dinoflagelltes in the lagoon of Trou aux Biches, Mauritius. Food and Agricultural Reasearch Council, Réduit, Mauritius, pp 211-217

Koike K, Ishimaru T, Murano M (1991) Distributions of benthic dinoflagellates in Akajima Island, Okinawa, Japan. Nippon Suisan Gakkaishi 57:2261-2264

Mangialajo L, Bertolotto R, Cattaneo-Vietti C, Chiantore M, Grillo C, Lemee R, Melchiorre N, Moretto P, Povero P, Ruggieri N (2008) The toxic benthic dinoflagellate Ostreopsis ovata: Quantification of proliferation along the coastline of Genoa, Italy. Mar Pollut Bull 56:1209-1214

Pistocchi R, Pezzolesi L, Guerrini F, Vanucci S, Dell'Aversano C, Fattorusso E (2011) A review on the effects of environmental conditions on growth and toxin production of Ostreopsis ovata. Toxicon 57:421-428

Rhodes L (2011) World-wide occurrence of the toxic dinoflagellate genus Ostreopsis. Schmidt. Toxicon 57:400-407

Shears NT, Ross PM (2009) Blooms of benthic dinoflagellates of the genus Ostreopsis an increasing and ecologically important phenomenon on temperate reefs in New Zealand and worldwide. Harmful Algae 8:916-925

Steidinger KA, Tangen K (1997) Dinoflagellates. In: Tomas CR (ed) Identifying marine phytoplankton. Academic Press, Florida, USA pp 387-584

Taylor FJR (1979) A description of the benthic dinoflagellate associated with maitotoxin and ciguatoxin, including observations on Hawaiian material. In: Taylor DL, Seliger HH (eds) Toxic dinoflagellate blooms. Elsevier North Holland, New York, pp 71-76

Taylor FJR, Fukuyo Y, Larsen J (1995) Taxonomy of toxic dinoflagellates. In: Hallegraeff GM, Anderson DM, Cembella AD (eds) Manual on harmful marine microalgae. IOC manuals and guides, No.33, UNESCO, pp 283-317

Vila M, Garcés E, Masó M (2001) Potentially toxic epiphytic dinoflagellate assemblages on macroalgae in the NW Mediteraanean. Aquat Microb Ecol 26:51-60

Yasumoto T, Oshima Y, Murakami Y, Nagajima I, Bagnis R, Fukuyo Y (1980) Toxicity of benthic dinoflagellates found in coral reef. Bull Japanses Soc Sci Fish 46:327-331 